\title{
Sediment load estimation in combined sewer systems located in semi-arid areas: a case study
}

\author{
A. Trapote $^{1} \&$ R. Egea ${ }^{2}$ \\ ${ }^{1}$ Department of Civil Engineering, University of Alicante, Spain \\ ${ }^{2}$ Empresa Municipal de Aguas y Saneamiento de Murcia \\ EMUASA, Spain
}

\begin{abstract}
This paper analyses the Pisano model, commonly used to estimate sediment load in combined sewer systems, and it is discussed its validity in semi-arid areas, which are characterized by irregular and scarce rainfall with short and intense precipitations. The model was applied to the sewer systems of eight watersheds of the city of Murcia (Spain) and it was verified that the value of the sediment load was much lower than the actual results obtained. Upon adjusting the original model by introducing typical semi-arid climatic factors, mainly periods of dry weather, it has been found that the real and theoretical values virtually coincide. The results obtained show that the sediment load is strongly influenced by periods of dry weather, which may be extremely prolonged in semi-arid areas, sometimes extended over 80 days. The results allow the planning of sewer system cleaning in order to prevent potential environmental impact caused by sewer system overflow into water channels during periods of intense rainfall.
\end{abstract}

Keywords: sediment load, dry weather periods, semi-arid areas, combined sewer systems, urban runoff, Pisano model.

\section{Introduction}

Sediments deposited in the combined sewerage systems during periods of dry weather generate contaminant loads that may potentially affect the receptor channels. Therefore, these loads must be controlled, both in their site of origin and downstream, through the proper management of these infrastructures [1].

Indeed, rainfall may displace the accumulated contamination across the urban surfaces during dry periods, transporting this contaminating load towards the 
sewerage network. The sediment load deposited in the base of the collectors may cause hydraulic functioning problems in the sewerage networks and the contamination of the receptor measures, in the case of an accidental spill occurring during periods of intense rainfall [2,3], with the potential contamination depending greatly on its size and origin [4]. At the same time, the increase in the flow rate may lead to the partial or total re-suspension of material that has already solidified in the combined collectors, which, along with the contamination displaced by the urban runoff, increases the contaminant load that may reach the channels and which often have a low capacity of self-purification, thereby creating environmental issues. The effect of the re-suspension of the sediments in the collectors varies according to rainfall levels, the slope of the collectors and the type of network [5].

One of the first studies of the contamination generated by urban runoff was conducted by Sutherland and Jelen [6] for the American Public Works Association (APWA), with the goal of identifying and quantifying the sources of urban runoff contamination. The results of this study highlighted the fact that the contamination of the urban runoff came from the sediments accumulated on the street surfaces, from contaminants found in the green areas of the deposits generated by the wind and from other substances derived from motor vehicles. It was also found that the fraction corresponding to the sediments and accumulated materials in the streets was the most relevant in quantitative terms. In other words, this was the part that requires improvement in order to reduce contamination. Sartor et al. [7] studied accumulation and the displacement of contamination in dry weather, concluding that the contaminants found in the urban streets tend to be organic and mineral (sand, silt and dust), and that the quantity of the contaminants present in the urban pavements depend on the time passing since the last cleaning or since the last rainfall episode. Therefore, it was found that a relevant aspect for the accumulation and displacement of sediments coming from urban runoff is its evolution over time, in that the contaminating load may be obtained by relating the type of watershed (ground uses) with the time since the last cleaning or rainfall episode. It was also found that the characteristics of the sediments also vary over time [8], and that the processes occurring in the sediments deposited during dry weather periods are comparable in urban basins with the types of sewerage networks and the uses of similar grounds [9].

For years, studies have been carried out in regards to the phenomena of erosion and the transport of sediments deposited in sewerage networks [10, 11]. Specifically, in the field of modernization, there are accumulation-runoff models for contaminants such as the EPA-SWMM and HEC-RAS models, making it possible to obtain the level contamination existing in a watershed at any given time. Models have also been created for the development of the transport of sediments in sewerage networks $[4,12]$, numeric models [13, 14] and artificial neural networks [15].

From a practical point of view in regards to the management of the sewerage networks, the most frequently used models for estimating the daily load of sediments in combined sewerage networks in dry weather periods were developed by Pisano et al. [16] for the Environmental Protection Agency (EPA), known as 
the "Elaborate Model", the "Intermediate Model" and the "Simplest Model" for the sewerage networks of certain metropolitan watersheds of the cities of Boston (MA, USA), Fitchburg (MA, USA) and Cleveland (OH, USA). In these predictive models, the hypothesis is that the propensity for the deposit of sediments is related to the location of the collectors in the sewerage network, the size (diameter) of the same, their slopes and the concentration of sediment in the wastewater.

Fraser and Ashley [2] proposed a modification of the Pisano models, expressing them based on the critical tension and the shear stress in the base of the piping, in order to obtain the percentage of solids in suspension that are deposited across the length of the collectors, introducing the width values of the sediment deposits in the base and their maximum value in order to estimate the long term deposit of settlements.

However, few studies have applied the Pisano models to actual case studies. Seco [17] used the Intermediate Model (Boston) to estimate the depth of the sediments deposited in the base of the collectors of the Granollers (Barcelona, Spain) watershed, and confirmed the influence of the rainfall characteristics of the area under study in relation to the depth of the sediments with the slope of the collectors and the diameters of the same.

The objective of our study is to determine the validity of the Simplest Model for use in semi-arid areas, where irregular and scarce rainfall lead to prolonged periods of dry weather, causing a major accumulation of sediments in the urban watersheds. This model has been applied to the collective sewerage networks of 8 urban sub-basins in the city of Murcia $\left(37^{\circ} 59^{\prime} 00^{\prime \prime} \mathrm{N}, 01^{\circ} 07^{\prime} 00^{\prime \prime} \mathrm{W}\right)$, located in the Mediterranean coast in the southeast Spanish peninsula, typically having a semi-arid climate. The theoretical results of the model have been contrasted with the real data measured for these networks. The results reveal that the sediment load is strongly influenced by the specific local climates, mainly in terms of rainfall.

The scope of this objective may permit the optimal planning of the cleaning operations of the sewerage networks, acting on the most sensitive points of the network and thereby preventing environmental conditions in the receiving channels, in the case of overflows or accidental sewer system spills.

\section{Methodology}

\subsection{Characterization of the analysed case}

The area under study (Murcia, Spain) is characterized by scarce and irregular rainfall, typical of semi-arid climates, with very intense rainfalls $(200 \mathrm{~mm}$ in a 24 hour period) of short duration ( $\leq 120 \mathrm{~min})$, and with alternating dry and humid years. Figure 1 reveals the annual distribution of precipitation in the 1993-2014 period, ranging between a minimum of $143.45 \mathrm{~mm}$ (1999) and a maximum of $487.95 \mathrm{~mm}$ (1993), with an average of $272.76 \mathrm{~mm}$. Specifically, in 2014 (the year of the study) total precipitation was $187.37 \mathrm{~mm}$, with an average dry weather period of 31.2 days. 


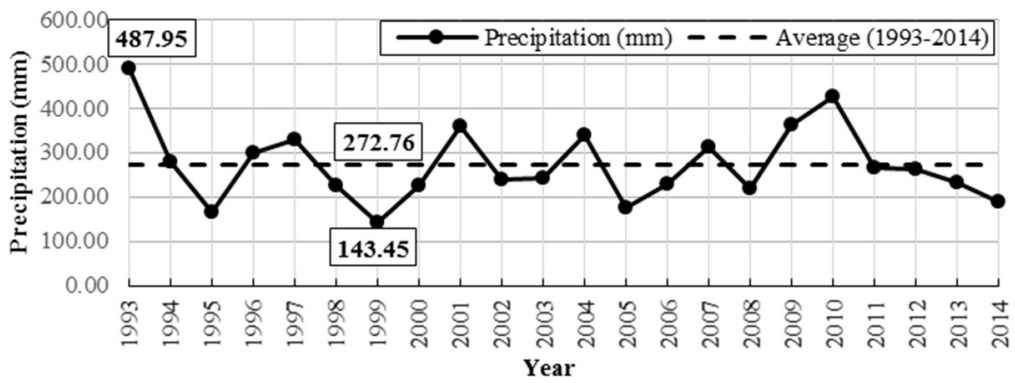

Figure 1: Annual precipitation in the study area between 1993 and 2014 (EMUASA).

The sewerage network was cleaned with pressurized water, in the segments located between the manholes and sediments were extracted from well to well.

Quantifications were made based on weighing using the balances of the transport trucks. The average density of the sediments was $1.42 \mathrm{t} \mathrm{m}^{-3}$, in the CIRIA (Construction Industry Research and Information Association) study line, determining that in the collective sewer networks the density of the sediments is inferior to $1.5 \mathrm{t} \mathrm{m}^{-3}$ [18].

The selected study scene was the sewerage networks (collective) of 8 subbasins. In table 1, the characteristic data from each of these sub-basins is described, where $\mathrm{L}$ is the length of the network, $\mathrm{S}$ is the average slope, $\mathrm{D}$ is the average diameter of the collectors and A is the area of the tributary sub-basin.

Table 1: Characteristic data from the examined sewerage networks (EMUASA).

\begin{tabular}{|r|l|r|r|r|r|}
\hline $\mathrm{N}^{\mathrm{o}}$ & Sub-catchment & \multicolumn{1}{c|}{$\mathrm{L}(\mathrm{m})$} & $\mathrm{S}(\mathrm{m} / \mathrm{m})$ & $\mathrm{D}(\mathrm{m})$ & \multicolumn{1}{c|}{ A (ha) } \\
\hline 1 & Infante & 44,921 & 0.0006 & 0.465 & 175.67 \\
\hline 2 & Faroliva & 2,639 & 0.0013 & 0.669 & 43.70 \\
\hline 3 & El Ferrocarril & 10,354 & 0.0014 & 0.376 & 45.42 \\
\hline 4 & Central & 91,725 & 0.0018 & 0.542 & 450.53 \\
\hline 5 & Algezares II & 4,008 & 0.0037 & 0.567 & 63.21 \\
\hline 6 & Plaza Circular & 14,599 & 0.0043 & 0.482 & 52.50 \\
\hline 7 & Patiño & 9,041 & 0.0062 & 0.278 & 87.58 \\
\hline 8 & Juan XXIII & 11,906 & 0.0113 & 0.355 & 87.91 \\
\hline & \multicolumn{6}{|c|}{ Total } & 189,193 & & & $1,006.52$ \\
\hline
\end{tabular}

The selection criteria of the examined networks were based on consideration of the greatest possible diversity of sewerage network lengths $(2,639-91,725 \mathrm{~m})$, slopes $(0.0006-0.0113 \mathrm{~m} / \mathrm{m})$, sub-basin extension (43.70-450.53 ha) and collector 
diameter $(0.278-0.699 \mathrm{~m})$. In addition, the respective values must have been representative of the sewerage networks of the study area.

The provision of potable water in the study area is $0.175 \mathrm{~m}^{3}$ (cap d) $)^{-1}$, a quantity that when multiplied by a return coefficient of 0.85 , results in a daily mean flow unit of wastewaters of $0.149 \mathrm{~m}^{3}$ (cap d) ${ }^{-1}$. This flow may fluctuate over time, not only due to the variations in the provision of potable water (as may occur in any other case), but also, and mainly, due to water infiltrations from the groundwater level, traditional irrigation channels that run through the underground, building drains, etc. Specifically, the high groundwater levels of the study area means that, at times, the sewerage networks may become partially submerged.

\subsection{Model used to estimate the sediment load}

This study has used the "Simplest Model", which was formulated as follows [16, 17, 19-22] (SI units):

$$
T S=0.000709 \cdot L^{1.063} \cdot S^{-0.438} \cdot q^{-0.51} \quad\left(\mathrm{R}^{2}=0.845\right)
$$

where TS is the daily sediment load, L is the total length of the network, $\mathrm{S}$ is the average slope of the collectors and $\mathrm{q}$ is the average daily unit flow of the waste water.

In eqn (1), it is assumed that the collectors are clean; that is, that there are no sediment deposits prior to the storm event, and that proper maintenance practices (cleaning) are followed for the network. Otherwise, it shall be necessary to apply corrective factors to the results obtained for the clean collectors. Thus, eqns (2) and (3) may be used to consider, respectively, an average level of maintenance (initial deposit depth of between 25.4 and $76.2 \mathrm{~mm}$ ), $\mathrm{TS}_{\mathrm{im}}$, and a low level of maintenance (initial deposit depth of between 76.2 and $152.4 \mathrm{~mm}$ ), $\mathrm{TS}_{\mathrm{pm}}$ [16] (SI units):

$$
\begin{array}{ll}
T S_{i m}=1.10 \cdot q^{-0.076} \cdot T S & \left(\mathrm{R}^{2}=0.988\right) \\
T S_{p m}=1.12 \cdot q^{-0.084} \cdot T S & \left(\mathrm{R}^{2}=0.999\right)
\end{array}
$$

Regarding the conditions of collector self-cleaning, Pisano considers the Shields [23] parameter of shear stress, given by the following expression:

$$
\tau=\gamma \cdot R \cdot S
$$

where $\tau$ is the shear stress in the base of the collector, $\gamma$ is the specific weight of water, $\mathrm{R}$ is the hydraulic radius and $\mathrm{S}$ is the slope. 


\section{Results and discussion}

\subsection{Previous analysis of the Simplest Model}

Apparently, the parameter having the greatest influence in the results of the Simplest Model is the total length of the sewerage network (L). However, its effect may be minimized by expressing the values of TS per meter of collector length $\left(\mathrm{kg}(\mathrm{d} \mathrm{m})^{-1}\right)$; that is, as a daily sediment unit load or simply, the unit load (TSu). The eqn (1) may be described as:

$$
T S u=0.000709 \cdot L^{0.063} \cdot S^{-0.438} \cdot q^{-0.51}
$$

In table 2, the values of the terms of eqns. (1) and (5) are broken down for the sewerage networks under study.

Table 2: $\quad$ Breakdown of the values of the terms in eqns (1) and (5) of the case study.

\begin{tabular}{|l|l|r|r|r|r|r|r|r|}
\hline $\mathrm{N}^{\mathbf{o}}$ & Sub-catchment & $\mathrm{L}(\mathrm{m})$ & $\begin{array}{r}\mathrm{L}^{1.063} \\
(\mathrm{eqn}(1))\end{array}$ & $\begin{array}{c}\mathrm{L}^{0.063} \\
(\mathrm{eqn}(5))\end{array}$ & $\mathrm{S}(\mathrm{m} / \mathrm{m})$ & $\mathrm{S}^{-0.438}$ & $\begin{array}{c}\mathrm{q} \\
\left(\mathrm{m}^{3}(\mathrm{cap} \mathrm{d})^{-1}\right)\end{array}$ & $\mathrm{q}^{-0.51}$ \\
\hline 1 & Infante & 44,921 & $\mathbf{8 8 , 2 1 7}$ & $\mathbf{1 . 9 6}$ & 0.0006 & 25.77 & 0.149 & 3.05 \\
\hline 2 & Faroliva & 2,639 & $\mathbf{4 , 3 3 5}$ & $\mathbf{1 . 6 4}$ & 0.0013 & 18.37 & 0.149 & 3.05 \\
\hline 3 & El Ferrocarril & 10,354 & $\mathbf{1 8 , 5 3 8}$ & $\mathbf{1 . 7 9}$ & 0.0014 & 17.78 & 0.149 & 3.05 \\
\hline 4 & Central & 91,725 & $\mathbf{1 8 8 , 4 1 9}$ & $\mathbf{2 . 0 5}$ & 0.0018 & 15.93 & 0.149 & 3.05 \\
\hline 5 & Algezares II & 4,008 & $\mathbf{6 , 7 5 9}$ & $\mathbf{1 . 6 9}$ & 0.0037 & 11.62 & 0.149 & 3.05 \\
\hline 6 & Plaza Circular & 14,599 & $\mathbf{2 6 , 7 1 0}$ & $\mathbf{1 . 8 3}$ & 0.0043 & 10.86 & 0.149 & 3.05 \\
\hline 7 & Patiño & 9,041 & $\mathbf{1 6 , 0 4 9}$ & $\mathbf{1 . 7 8}$ & 0.0062 & 9.26 & 0.149 & 3.05 \\
\hline 8 & Juan XXIII & 11,906 & $\mathbf{2 1 , 5 0 5}$ & $\mathbf{1 . 8 1}$ & 0.0113 & 7.12 & 0.149 & 3.05 \\
\hline
\end{tabular}

It is found that, by considering the unit load (TSu) instead of the total load (TS), this results in the homogenization of the values and a significant reduction of the relative weight of $\mathrm{L}$, especially when comparing it to that of $\mathrm{S}$.

\subsection{Application of the Simplest Model to the case study}

Figure 2 shows the results of $\mathrm{TSu}$, the "theoretical" results, obtained when applying eqn (5) to the studied networks $(q=0.149)$, and the average unit loads in these networks (TSr), known as "real", together with the corresponding regression curves in function of S. As fig. 2 reveals, both regression curves are quite similar, with good fits to potential functions. However, the real values (TSr) are much greater than the theoretical values $(\mathrm{TSu})$ that are provided by the model, although there are diverse factors of the networks or of the study area that, as we shall see, contribute to reducing this difference. 


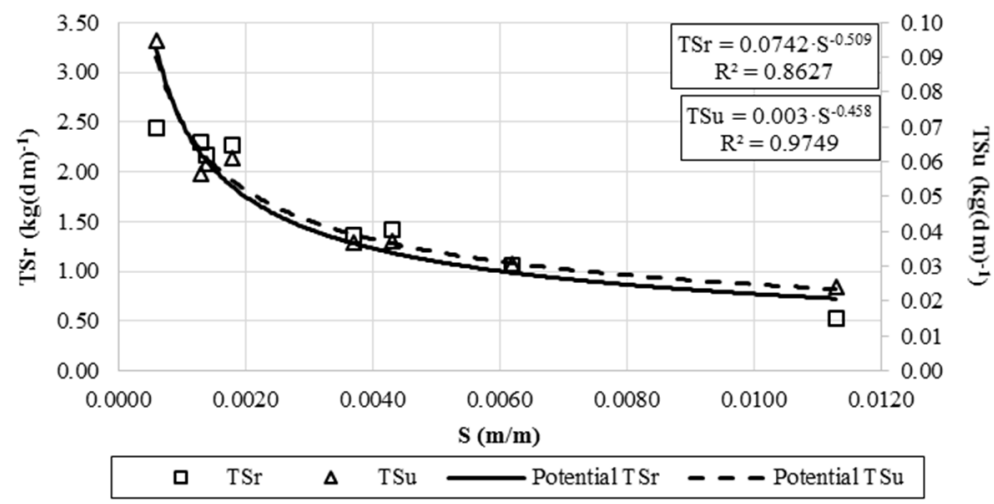

Figure 2: $\quad$ Real results (TSr) and theoretical results (TSu) of the sediment loads and regression curves corresponding to $\mathrm{S}$.

One of these is the level of maintenance of the sewerage system, which in the case of this study, is "intermediate". Therefore, combining eqns (2) and (5), the following expression of sediment unit load for the sewerage network with an intermediate maintenance level is reached (1st correction of the Simplest Model):

$$
T S u_{i m}=0.00078 \cdot L^{0.063} \cdot S^{-0.438} \cdot q^{-0.586}
$$

The application of the eqn (6) to the case study means increases of 30 to $50 \%$ (greater increase for greater slope) for the values obtained through application of eqn (5) for the clean sewerage network.

Another factor to be considered is rainfall, probably the most important factor due to its relationship with periods of dry weather. The patterns of the Pisano models were the sewerage networks of the city of Boston (and Fitchburg), whose climate (like that of Fitchburg) is humid continental, with annual precipitations of $1,111.50 \mathrm{~mm}$ and average dry periods of 2.7 days (http://www.usclimatedata.com/ climate/boston/massachusetts/united-states/usma0046). This data contrasts greatly with the areas studied, whose climate is semi-arid and has annual precipitation of $187.37 \mathrm{~mm}$ and average dry periods of 31.2 days (2014). Thus, the eqn (6) should be corrected in order to adapt it to the climatic characteristics of the study area. One way of doing this is by relating the dry periods of the study area (Murcia) with those of Boston, which in this case is: $31.2 / 2.7=11.6$. By weighing the eqn (7) with this magnitude, the following expression is reached (2nd correction of the Simplest Model):

$$
T S u^{\prime}=0.00905 \cdot L^{0.063} \cdot S^{-0.438} \cdot q^{-0.586}
$$

Figure 3 shows the regression curve of the theoretical values of TSu', obtained from eqn (7). Obviously, the curve of the real values (TSr) does not change. 


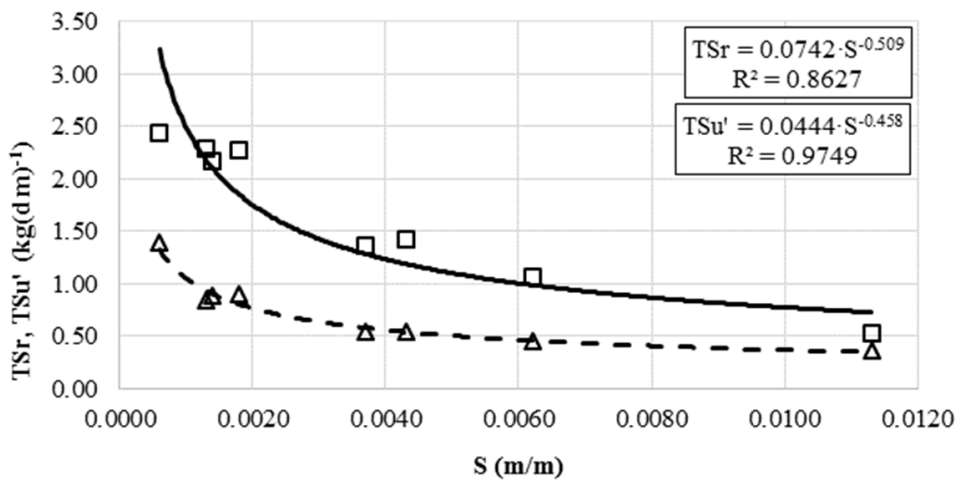

口 $\operatorname{TSr} \quad \boldsymbol{\Delta} \quad \mathrm{TSu}^{\prime} \longrightarrow$ Potential TSr $-\boldsymbol{-}$ - Potential TSu'

Figure 3: Real (TSr) and corrected theoretical (TSu') results of the unit sediment loads, and corresponding regression curves based on $\mathrm{S}$ (period of dry weather of 31.2 days).

As revealed in fig. 3, the theoretical regression curve is now much closer to the real curve, suggesting the strong influence of dry weather on the sediment load. In fact, for a dry period of 70 days, which is not unusual in semi-arid regions such as the study area, the theoretical and real results are practically identical, as seen in fig. 4 .

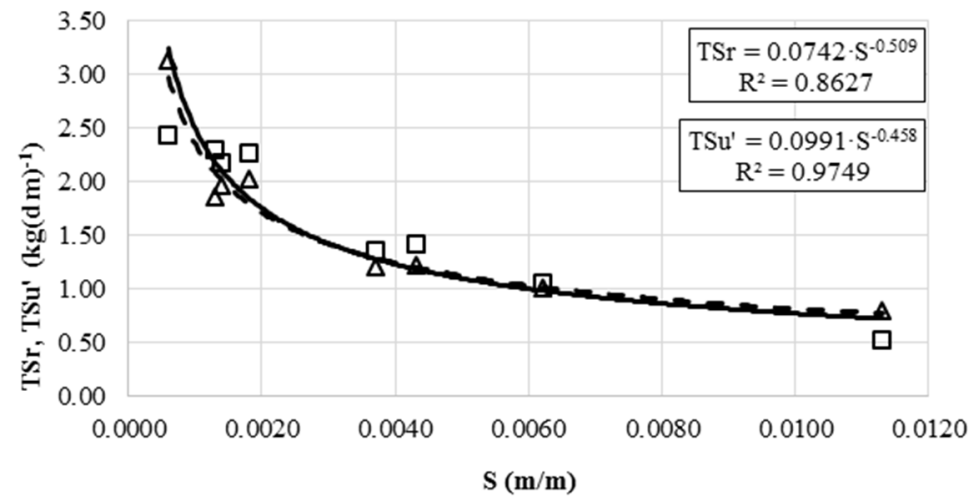

口 $\operatorname{TSr} \quad \Delta \quad \mathrm{TSu}^{\prime} \longrightarrow$ Potential T Sr $-\cdots$ Potential T Su

Figure 4: Real (TSr) and theoretical (TSu') results of the sediment load units and corresponding regression curves based on $\mathrm{S}$ (period of dry weather of 70 days). 
Accepting the overall validity of Pisano's Simplest Model, the fact that the real sediment loads measured were greater than those obtained using the theoretical model may be reasonably explained by the rainfall characteristics of the study area. Thus, clearly there is a decisive influence of dry weather periods, which, in the semi-arid regions, may be extremely prolonged, sometimes extending over 80 days.

As for the actual sediment load values of the sewerage networks, the regression curve responds to the following equation, whose high correlation coefficient $\left(\mathrm{R}^{2}\right.$ $=0.8627$ ) indicates the goodness-of-fit:

$$
T S r=0.0742 \cdot S^{0.509} \quad\left(\mathrm{R}^{2}=0.8627\right)
$$

\section{Conclusions}

This study analyses Pisano's Simplest Model (Boston \& Fitchburg), and evaluated its appropriateness for sewerage networks that are located in semi-arid climates, characterized by scarce and irregular rainfall, leading to extremely extended dry periods and thereby creating a major accumulation of sediments in the urban watersheds.

This model was applied to 8 sewerage networks of the city of Murcia (Spain), having a typically semi-arid climate and the theoretical values of the sediment load provided by the model were contrasted with the real data from the networks, finding considerably higher values for the real values as compared to the theoretical ones. Through successive corrections of the theoretical model, introducing local conditions, mainly the dry weather periods characteristic of the study area, the theoretical results approximate the real results, until almost coinciding, thus demonstrating the clear influence of local rainfall on sediment load.

Furthermore, it has been verified that the most determinant parameter in the sediment load is the slope, particularly when it is small $(\leq 0.004)$, increasing its influence dramatically when, furthermore, the flows are low $(\leq 0.150)$. In these cases of small slopes, and for the design purposes, it is recommended that the diameters of the collectors be oversized, in order to increase the hydraulic radius and, thereby increase the value of the shear stress of the base in order to improve the conditions of self-cleaning.

In addition, it has been verified that the influence of flow becomes less significant as the slope increases, so that for large slopes $(S \geq 0.008)$ the potential variation of the same barely affect the sediment load results. In intermediate ranges $(0.004<\mathrm{S}<0.008)$, the influence of the slope is more or less significant based on the function of the flow (greater influence when the flow is lower and vice versa), such that the combination of low flows $(q \leq 0.150)$ with small slopes $(S \leq 0.004)$ results in large increases in sediment loads. Therefore, the presence of high ground water levels, groundwater, etc., may cause infiltrations in the network that may result in fluctuation in the flows, altering the hydraulic functioning of the collectors, which shall most likely affect the quantity (and quality) of the sediment deposits. 
On the other hand, the length of the sewerage network was found to be insignificant when the sediment load was quantified by meter of collector length (unit load).

The results allow for the optimal planning of the cleaning of the sewerage network and the preventive intervention in the most sensitive points of the same, that is, where there are greater probabilities of sediment deposits (sections of lower slopes and flow). Thus, it may be possible to prevent environmental issues in the receiving channels, in the case of sewerage systems overflows during periods of intense rainfall, as are typical of semi-arid areas.

\section{Notation}

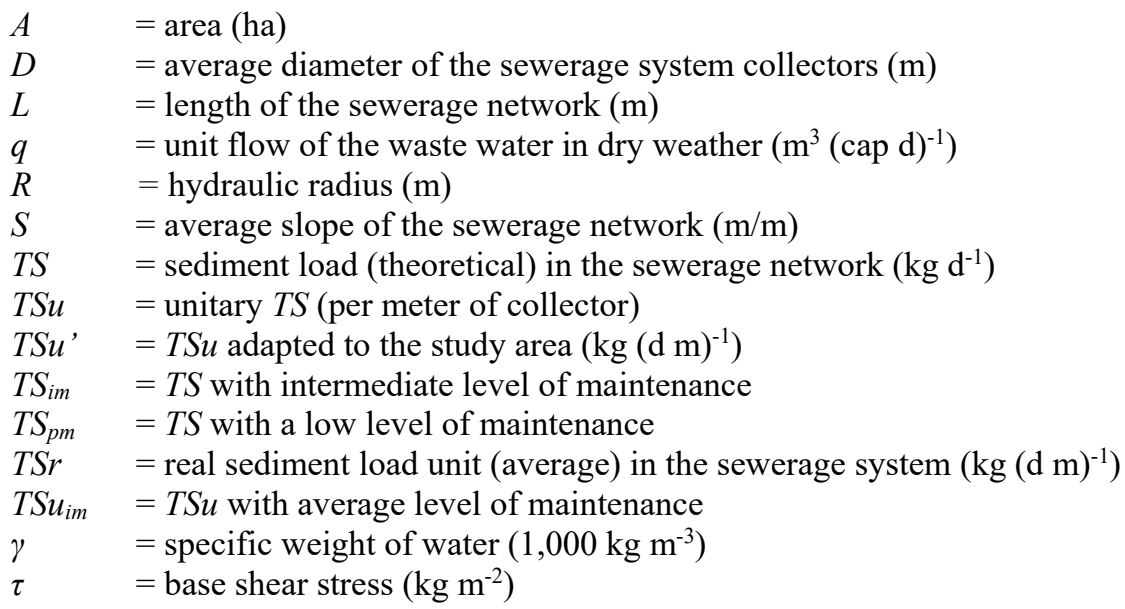

\section{Acknowledgements}

The authors wish to thank EMUASA for its collaboration in the carrying out of this study, and in particular to its General Manager, José Albaladejo Guillén, for his great disposition to the project, without which this study would not have been possible.

\section{References}

[1] Fan, C-Y., Field, R. \& Lai, F. Sewer Sediment Control: Overview of an EPA Wet-Wheather Flow Research Program (EPA/600/J-03/188), National Risk Management Research Laboratory, Cincinnati, OH (USA), 2003.

[2] Fraser A. \& Ashley R., A Model for the Prediction and Control of Problematic Sediment Deposits, Proceedings of the 8th International Conference on Urban Storm Drainage, Sydney, Australia, 1999. 
[3] Ahyerre, M. \& Chebbo, G., Identification of In-Sewer Sources of Organic Solids Contributing to Combined Sewer Overflows. Environmental Technology, 23(9), pp. 1063-1073, 2002.

[4] Träckner, J., Bönisch, G., Gebhard, V.R., Dirckx, G. \& Krebs, P., Modelbased assessment of sediment sources in sewers. Urban Water Journal, 5(4), pp. 277-286, 2008.

[5] Suárez, J., Jácome, A., Anta, J., Blanco, J.-P., Hernáez, D. \& Del Río, H., Implicaciones sobre la estación depuradora de la gestión de aguas pluviales en los sistemas de saneamiento unitario: estrategias de integración y afecciones sobre los procesos. Ingeniería Civil, 168, pp. 33-49, 2012.

[6] Sutherland, R.C. \& Jelen, S.L., Studies Show Sweeping has Beneficial Impact on Stormwater Quality, APWA Reporter 63(10), 1996.

[7] Sartor, J.D., Boyd, G.B. \& Agardy, F.J., Water pollution aspects of street surface contaminants. J. Water Pollut Control Fed., 46(3), pp. 458-467, 1974.

[8] Clegg, S., Forster, C.F. \& Crabtree, R.W., Sewer sediment characteristics and their variation with time. Environmental Technology, 13(6), pp. 561$569,1992$.

[9] Gasperi, J., Kafi-Benyahia, M., Lorgeoux, C., Moilleron, R., Gromaire, M.C. \& Chebbo, G., Wastewater quality and pollutant loads in combined sewers during dry weather periods. Urban Water Journal, 5(4), pp. 3053014, 2008.

[10] Ashley, R.M. \& Verbanck, M.A., Mechanics of sewer sediment erosion and transport. Journal of Hydraulic Research, 34(6), pp. 753-770, 1996.

[11] Butler, D., May, R. \& Ackers, J., Self-Cleansing Sewer Design Based on Sediment Transport Principles. Journal of Hydraulic Engineering, 129(4), pp. 276-282, 2003.

[12] Bertrand-Krajewski, J-L. \& Briat, P., Sewer sediment production and transport modelling: A literature review. Journal of Hydraulic Research, 31(4), pp. 435-460, 1993.

[13] Todeschini, S., Ciaponi, C. \& Papiri, S., Laboratory experiments and numerical modelling of the scouring effects of flushing waves on sediment beds. Engineering Applications of Computational Fluid Mechanics, 4(3), pp. 365-373, 2010.

[14] Creaco, E. \& Bertrand-Krajewski, J-L., Numerical simulation of flushing effect on sewer sediments and comparison of four sediment transport formulas. Journal of Hydraulic Research, 47(2), pp. 195-202, 2009.

[15] Ebtehaj, I. \& Bonakdari, H., Evaluation of Sediment Transport in Sewer using Artificial Neural Network. Engineering Applications of Computational Fluid Mechanics, 3(7), pp. 382-392, 2013.

[16] Pisano, W.C., Aronson, G.L., Queiroz, C.S., Blanc, F.C. \& O’Shaughnessy, J.C. Dry-Weather Deposition and Flushing for Combined Sewer Overflow Pollution Control, EPA-600/2-79-133 (NTIS PB80-118524), Environmental Protection Agency (EPA), Cincinnati, OH (USA), 1979. 
[17] Seco, R.I. In-sewer organic sediment transport. Study of sediments during wet-wheather from combined sewer systems in the Mediterranean region in Spain, Doctoral Thesis, Universidad Politécnica de Cataluña (Spain), 2014.

[18] Ackers, J.C., Butler, D. \& May, R.W.P., Design of sewers to control sediments problems, CIRIA (Construction Industry Research and Information Association), Report 141, London (UK), 1996.

[19] Pisano, W.C. \& Queiroz, C.S. Procedures for Estimating Dry Weather Pollutant Deposition in Sewerage Systems, Report No. EPA-600/2-77/120, NTIS PB 270 695, U.S. Environmental Protection Agency (EPA), Municipal Environmental Research Laboratory, Cincinnati, OH (USA), 1977.

[20] Pisano, W.C. \& Queiroz, C.S. Procedures for Estimating DryWeather Sewage InLine Pollutant Deposition-Phase II, Report No. EPA-600/284/020, NTIS PB 84141 480, U.S. Environmental Protection Agency (EPA), Municipal Environmental Research Laboratory, Cincinnati, OH (USA), 1984.

[21] Fan, C-Y. Sewer Sediment and Control. A Management Practices Reference Guide, EPA/600/R-04/059, National Risk Management Research Laboratory. Cincinnati, OH (USA), 2004.

[22] Temprano, J., Cervigni, M.G., Suárez, J. \&Tejero, J.I., Contaminación en redes de alcantarillado urbano en tiempo de lluvia: control en origen. Revista de Obras Públicas, 3352, pp. 45-57, 1996.

[23] Shields, A., Anwendung der aehnlichkeitsmechanik der turbulenzforchung auf die geschiebebewwegung, Mitt. der Preuss, Versuchsanstalt für Wasserbau und Schiffbau, Berlin (Germany), 1936. 